\title{
Effects of abiotic factors on co-occurring Carabus (Coleoptera: Carabidae) species
}

\author{
Dávid Fülöp ${ }^{1}$ (i) $\cdot$ Sándor Bérces ${ }^{2,3}$ (i) $\cdot$ Péter Szabó $^{4}$ (i) $\cdot$ Ferenc Samu $^{1}$ (i)
}

Received: 14 November 2019 / Accepted: 3 September 2020 / Published online: 15 September 2020

(C) The Author(s) 2020

\begin{abstract}
The members of the genus Carabus are among the most intensively studied beetle taxa, but many aspects of their autecology are still unexplored. We aimed to study the relationship between measured abiotic parameters and the spatial and temporal distribution of signature carabid species. Carabus assemblages were sampled by pitfalls at six sites belonging to two nearby locations, both forest habitats: in valley and in hill-top position. The sites showed variation in microclimatic and soil characteristics, to which the seven species caught showed specific spatial associations. Carabus scheidleri and C. coriaceus were ubiquitists, occurring at all sites. The habitat specialist $C$. violaceus germari indicated valley sites with high humidity, lower temperature, limy soil and higher $\mathrm{pH}$, whereas the other specialists, $C$. nemoralis and C. convexus were strongly associated with the dry, warm, more acidic hill habitat. Remaining species were associated with specific sites and environmental features. The species also exhibited specific phenological patterns corresponding with their habitat preference. Hill habitat species exhibited peak activity density during the hottest summer period, whereas most other species had an activity depression during that period. The results suggest that although Carabus activity density patterns are species specific, they are largely affected by temperature both spatially and temporally.
\end{abstract}

Keywords Ground beetles $\cdot$ Humidity $\cdot$ Temperature $\cdot$ Soil features $\cdot$ Activity $\cdot$ Sex ratio

\section{Introduction}

Modelling the influence of environmental abiotic factors on ecosystem functioning can be a difficult task, thus, the understanding of the abiotic drivers on biodiversity is the key to understand and predict the effects of climate change on species assemblages (De Laender et al. 2016). In this regard, ground dwelling invertebrates are ideal model organisms. Their changing phenology can be one of the first signs that

Dávid Fülöp

ocypus@gmail.com

1 Department of Zoology, Plant Protection Institute, ELKH Centre for Agricultural Research, Nagykovácsi út 26-30, Budapest H-1029, Hungary

2 Juhász-Nagy Pál Doctoral School, University of Debrecen, Egyetem tér 1, Debrecen H-4032, Hungary

3 Duna-Ipoly National Park Directorate, Költő u. 21, Budapest H-1121, Hungary

4 CER Institute of Evolution (IE), Karolina út 29, Budapest H-1113, Hungary makes environmental changes detectable (Eisenhauer et al. 2018). Although the first experiments dealing with the importance of abiotic factors influencing the activity of ground beetles date back to 1930's (Turin et al. 2003b), only a few papers deal with measured environmental factors affecting the otherwise relatively well studied genus Carabus (Coleoptera: Carabidae) (Cardenas and Hidalgo 2000; Kádár et al. 2017; Park et al. 2017). Information on the proximate responses of Carabus species to environmental variations is mostly based on naturalists' observations and intuitions, and classic autecological papers are still missing on this important group.

Members of the genus Carabus are large, often colourful, well studied members of the family Carabidae. They are usually considered as polyphagous predators of snails, slugs, insects and earthworms (Hůrka 1996). Their typical lifespan covers more than 1 year. Some species have overwintering larvae, as well. These long-living species are iteroparous, i.e. they are able to reproduce in more than one mating season (Andorkó and Kádár 2009). Eggs are deposited in the soil, larvae are active on the soil surface and pupation occurs in hollows in the ground. Very little is known about the biology and ecology of larvae due to the low capture rates and the difficulties in rearing them in the laboratory (Assmann 2003). 
The Hungarian Carabus species' checklist consists of 28 species, mainly associated with forest habitats. Each of the species is protected by Hungarian law. The seven Carabus species captured in our research were also characteristic forest dwelling species. Carabus convexus Fabricius, 1755 covers a wider habitat spectrum, besides forests also occurring in dry steppe habitats (Szél et al. 2007). The main activity periods are early spring and mid-summer which correspond to its reproduction period and to the emergence of tenerals (Kádár et al. 2015). Carabus coriaceus Linnaeus, 1758 is an eurytopic species mainly living in forests (Szél et al. 2007); active throughout the year, with the main activity peak during August (Turin et al. 2003a, b; Kádár et al. 2015). Carabus violaceus germari Sturm, 1815 is a common, eurytopic subspecies that occurs in forests, steppe vegetation and human settlements (Szél et al. 2007). This taxon is considered as separated species by some author (Szél et al. 2007) and by the Hungarian Law. Most of the information about it are taken from C. violaceus Linnaeus, 1758 data (Turin et al. 2003a, b; Kádár et al. 2015). Carabus hortensis Linnaeus, 1758 and C. nemoralis O.F. Müller, 1764 are both silvicol, eurytopic species (Szél et al. 2007). Carabus nemoralis is typical in thermophilic oak forests (Szél et al. 2007). The adults are active from early spring until about July, when they enter an aestivation diapause (Turin et al. 2003a, b). Carabus scheidleri Panzer, 1799 is widely distributed, mainly in hardwood forests (Szél et al. 2007). With some variation, it usually exhibits two activity peaks during a year (Turin et al. 2003a, b; Andorkó and Kádár 2009). This is allowed by its flexible reproductive periods (Thiele 1977), mainly caused by the ability of the larvae to develop either under summer or winter conditions (Andorkó and Kádár 2006). Carabus ullrichii Germar, 1824 is another silvicol species which also might occur in grassy habitats (Růžičková and Veselý 2018). It has two activity peaks in a season.

The most widely used method to investigate carabid assemblages is pitfall trapping. Pitfall trap catches are interpreted as activity density, because these figures are a function of both population density and the mobility of the individuals. Mobility is influenced by biotic and abiotic factors. Many biotic factors are innate, such as species identity and sex. Life history events, determining the occurrence of developmental stages can be in interaction with environmental factors. Sex-related mobility differences may cause virtual female or male dominance. For instance, there is a female bias in activity density during the egg laying period which requires lots of movements by the females. Conversely, males are usually more active during the mating season (Kádár et al. 2015), while variability in movement activity is influenced by feeding conditions in both sexes (Szyszko et al. 2004).

Activity density is also influenced by abiotic factors (Luff 1975; Lövei and Sunderland 1996) including temperature and humidity. The effects of these variables were studied under both laboratory (Thiele 1977) and field conditions (Refseth 1984; Cardenas and Hidalgo 2000; Turin et al. 2003a, b; Brouat et al. 2004; Kádár et al. 2017; Park et al. 2017). Temperature has been long considered to be the most important abiotic factor in influencing Carabus activity (Néve 1994) but it's effect was usually studied as a proximate factor acting at the time of the behavioural observation (Althoff et al. 1994; Néve 1994; Weber and Heimbach 2001; Růžičková and Veselý 2018). Only very few studies exist to statistically test the impact of temperature at longer timescales (Kádár et al. 2017; Park et al. 2017).

Most of the studies that dealt with the effect of the temperature did so by neglecting the effect of humidity. While relative humidity is not entirely independent from temperature, under the same temperature humidity may vary considerably, and this may have a high impact on the activity pattern of carabids. Currently the role of humidity is a controversial topic. Humidity was suggested as the principal component responsible for changes in carabid communities, however, this was based on environmental classification and not direct measurement of the factor (Šustek 2007). Other reports attribute much less significance to humidity (Huk and Kuhne 1999; Park et al. 2017). A recent study emphasizes that the effects of both climatic variables strongly influence local carabid communities (Park et al. 2017).

The larval development of Carabus spp. is strongly dependent on soil features (Paarmann 1973; Paarmann 1986), however, soil also plays a role in Carabus adult autecology via affecting the biotic environment through its chemical components, physical structure and by being in interaction with microclimate. The occurrence of some species is bound by special pH requirements (Weber 1966; Franzen 1995; Matern et al. 2007), although it is not clear whether this is a direct effect of the soil or a consequence of their prey's soil preference (Casale et al. 1998; Assmann et al. 2000). Even less is known about the effect of other natural chemical factors in the soil (Turin et al. 2003a, b). The effect of soil contamination, including that of heavy metals have been studied in more detail (Butovsky 2011; Koivula 2011; Tőzsér et al. 2019), but there are highly variable responses, which could arise from the fact that as predators the exposure of Carabus spp. to heavy metals probably depend more on the concentration in their prey than on the bioavailable concentration in the soil (Šerić Jelaska et al. 2014).

The main goal of the present study was to explore the relationship between measured abiotic parameters and the occurrence of signature carabid species. We investigated the effects of microclimatic factors (humidity, air temperature) and soil parameters on the spatial distribution of seven Carabus species. We also analysed how seasonal meteorological changes have affected activity density changes in the investigated species. We also analysed sex ratios in the pitfall catches as a function of the abiotic factors. 


\section{Materials and methods}

Pitfall trapping was performed near the village Solymár, north of the Hungarian Capital Budapest between 19.04.201304.10.2013 at two locations: (i) Alsó-Jegenye valley along the bank of Paprikás-rivulet (later referred to as "valley") and (ii) Felső-patak hill (later referred to as "hill") at $500 \mathrm{~m}$ distance from the first location. The valley habitat is located next to the village; it is a natural forest following the bank of the rivulet with high anthropogenic disturbance and with many invasive and indigenous plant species (Fallopia japonica, Parthenocissus inserta, Dryopteris filix-mas). The hill habitat is a natural forest, belonging to the Querco petraeae - Carpinetum association. At both locations three sampling sites were designated (valley: V1 (47 $35.098^{\prime} \mathrm{N}$; $\left.18^{\circ} 56.749^{\prime} \mathrm{E}\right), \mathrm{V} 2\left(47^{\circ} 35.064^{\prime} \mathrm{N} ; 1^{\circ} 56.734^{\prime} \mathrm{E}\right), \mathrm{V} 3$ (4735.054' N; $\left.18^{\circ} 56.734^{\prime} \mathrm{E}\right)$; hill: H1 $\left(47^{\circ} 35,094^{\prime} \mathrm{N}\right.$; $\left.18^{\circ} 57.164^{\prime} \mathrm{E}\right), \mathrm{H} 2\left(47^{\circ} 35.130^{\prime} \mathrm{N} ; 18^{\circ} 57.166^{\prime} \mathrm{E}\right), \mathrm{H} 3$ $\left.\left(47^{\circ} 35.115^{\prime} \mathrm{N} ; 18^{\circ} 57.151^{\prime} \mathrm{E}\right)\right)$. Samples were taken with five pitfall traps per site, with four traps in the corners of a square of $5 \mathrm{~m}$ side length, and one trap in the middle of the square (Fig. 1). The traps were filled with $70 \%$ ethylene glycol solution and were emptied fortnightly. The samples were stored in $70 \%$ ethanol before sorting their material under stereomicroscope. For more details on the sampling see (Csonka 2017).

To describe variation in microclimatic conditions across sites, relative humidity $(\mathrm{RH})$ and temperature $(\mathrm{T})$ were recorded with Voltcraft DL-121TH USB Data Logger, at every site attached to the very base of a nearby tree, between 14.06.2013-24.06.2013. We used the maximum, minimum, and average daily values in statistical analysis. Spatial variation in soil conditions was established by taking soil samples at each site. Soil samples were taken from the "A layer" of the soil at all trapping sites. Analysis was done by the Institute for Soil Sciences and Agricultural Chemistry, Centre for Agricultural Research based on MÉMNAK: MSZ-08-0202-
1977 protocol (pH, structure, dissolved salt, humus, $\mathrm{CaCO}_{3}$, $\mathrm{P}, \mathrm{K}, \mathrm{N}$ content).

To describe longer term, seasonal temporal variation, meteorological data representing the entire study area and covering the whole trapping period was obtained from www. idokep.hu. We calculated average values of temperature and relative humidity for the sampling intervals from the daily data provided by the homepage administrator.

Spatial differences in microclimatic variables were analysed using General Linear Models with mixed effects (MGLM). We constructed models with daily average temperature and humidity being the explanatory variables, with sites nested within habitat as factorial variables, and the days as random factors. The effect of the seasonal variation in meteorological variables on the activity density of Carabus species was tested with Generalized Linear Models (GZLM) with Poisson distribution and log link function in R 3.6.1 (R Core Team 2019) using multistage approach. First the effect of average temperature and average humidity were tested, in case of no significant results the minimum and maximum values were tested. A stepwise model selection was carried out in forward/backward and backward/forward directions using the Akaike Information Criterion (AIC). If overdispersion was detected (Residual Deviance is greater than the degrees of freedom), quasi-Poisson models were used. Genders of the three most abundant species were tested separately with the same procedure.

Species association with the environmental variables was visualized with Redundancy Analysis (RDA) in CANOCO (ter Braak and Smilauer 2012), significance of habitat associations was tested by calculating Indicator Values (IV) by Indicator Value Analysis (Dufrêne and Legendre 1997) performed in PC-Ord 6.0 (McCune and Mefford 2011). Sex ratio differences were tested according to Wilson and Hardy (2002).
Fig. 1 Locality of sampling sites and the arrangement of traps at sites. (Source of map: Google maps)

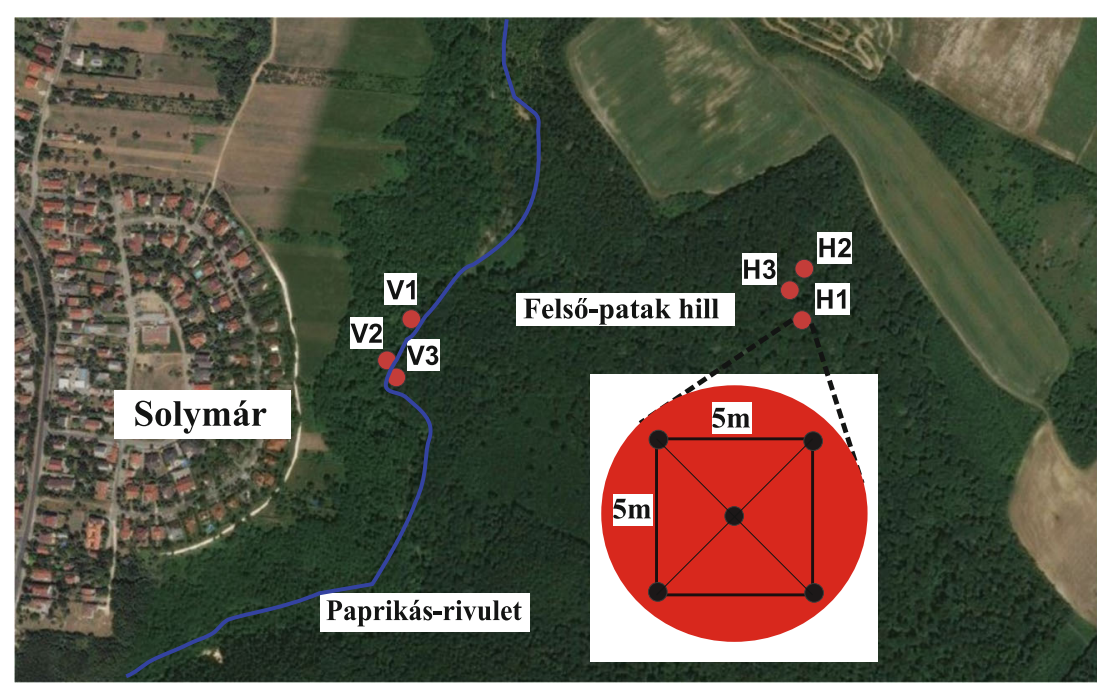




\section{Results}

\section{Spatial variation in microclimatic and soil conditions}

There were significant differences in the daily average temperature and daily average humidity data between the hill and the valley habitat (MGLM Temperature, effect of habitat: $\mathrm{F}=$ 309.1; d.f. $=1,50 ; p<0.0001$; MGLM Humidity, effect of habitat: $\mathrm{F}=100.8$; d.f. $=1,50 ; p<0.0001$; Fig. 2). The sampling sites within the habitats were not homogeneous with respect to the microclimatic variables (MGLM Temperature, effect of site(habitat): $\mathrm{F}=29.0$; d.f. $=4,50 ; p<0.0001$; MGLM Humidity, effect of site(habitat): $\mathrm{F}=15.2$; d.f. $=4$, $50 ; p<0.0001 ;$ Fig. 2). Samples from the hill contained less carbonate $(0.14-0.47 \mathrm{~m} / \mathrm{m} \%)$ than from the valley $(6.11-$ $15.7 \mathrm{~m} / \mathrm{m} \%$ ), presumably due to wash out of $\mathrm{CaCO}_{3}$. Correspondingly, soils were slightly acidic on the hill (pH 5.9-6.7) and nearly neutral, slightly alkaline (pH 7.27.3 ) in the valley. Phosphate and nitrogen content was more variable, independently of habitat. Valley 3 site had the highest $\mathrm{P}$ concentration $(294 \mathrm{mg} / \mathrm{kg})$, while $\mathrm{N}$ concentrations were the highest at V2 and $\mathrm{H} 3(0.35$ and $0.34 \mathrm{~m} / \mathrm{m} \%$, respectively).
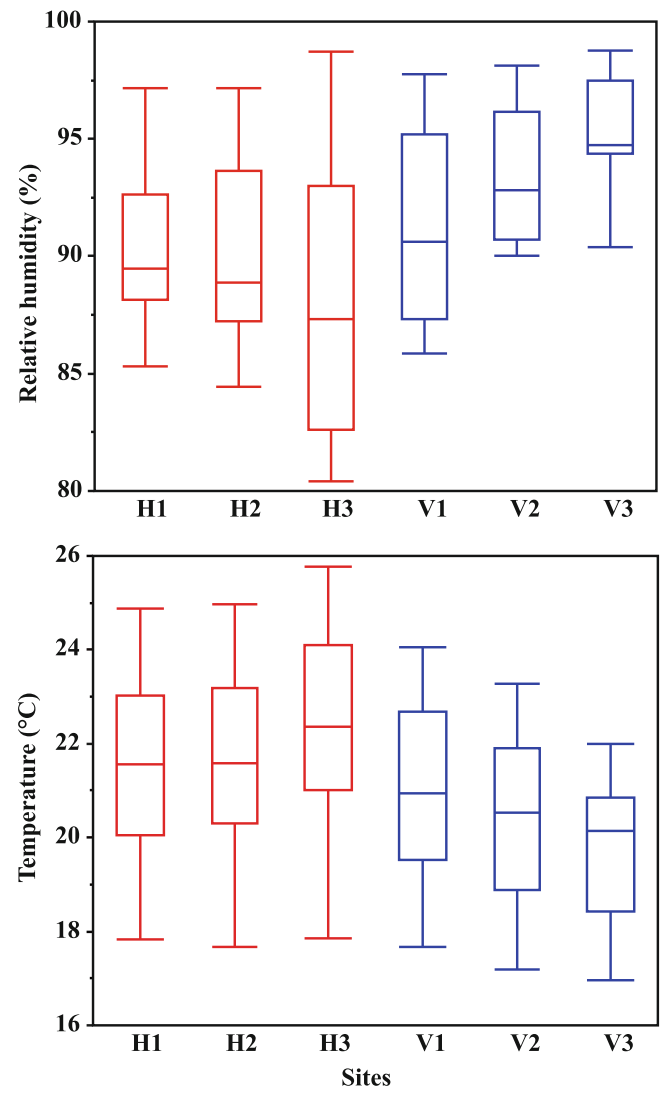

Fig. 2 Box-plot of microclimatic data (vertical lines: minimum and maximum values, 25 th and 75 th percentiles and median. Red: hill habitat, blue: valley habitat

\section{Spatial variance in Carabus distribution}

All together 573 specimens of seven Carabus species were collected during the sampling period; their occurrence and abundance was different at the sampling sites (Table 1). Taking a combination of microclimate and main soil variables, the first two axes in the constrained ordination explained $87.4 \%$ of the variation in species distribution cumulatively (RDA: Eigenvalue (axis 1) $=0.59$; Eigenvalue (axis $2)=0.28)($ Fig. 3). The most abundant species, C. scheidleri, positioned the closest to the ordination origo, occurred at all sites. Out of the sub-dominant, but also ubiquitous species, $C$. coriaceus showed no pronounced preference for either habitat, but C. v. germari was much more frequent in the valley habitats described by high humidity, lower temperature, limy soil and higher $\mathrm{pH}$. The ordination plot reveals that $C$. nemoralis and $C$. convexus were strongly associated with the dry, warm and more acidic hill habitat. These habitat associations for each mentioned species were marginally significant $(p=0.1)$ in the performed Indicator Value Analysis (valley habitat indication: $\operatorname{IV}(C$. v. germari $)=93.8$; hill habitat indication: $\operatorname{IV}(C$. nemoralis $)=100 ; \operatorname{IV}(C$. convexus $)=86.5)$. Carabus ullrichii specimens seem to avoid the bank of the rivulet (V3 site), which was the most humid site. Carabus convexus was only recorded from samples from one side of the rivulet and from the hill habitats (V3, H1-3), but was missing from the other bank (V1-2), while $C$. hortensis was recorded with greater abundance only from V3.

\section{Seasonal variation in meteorological variables and Carabus activity}

Fortnightly average temperature and humidity had no significant effect on the activity of any Carabus species. Minimum temperature positively correlated with the activity of $C$. convexus, $C$. nemoralis and $C$. scheidleri specimens. The later was also positively affected by the maximum humidity as well. All Carabus species were active during the whole sampling period, however, they showed markedly different seasonal activity patterns (Fig. 4). With the exception of $C$. nemoralis and $C$. coriaceus they had a moderate spring activity period during May and a more pronounced activity period later in the summer, although they reacted differently to the hottest, driest periods. Carabus convexus, C. nemoralis and $C$. ullrichii were the most active during the hottest and driest periods. Carabus coriaceus showed some kind of aestivation reducing its activity during this time, resulting in a bimodal pattern peaking in June and September. Carabus scheidleri also exhibited a bimodal phenology, with highest activity at the end of June, however this species had the second, albeit smaller, peak during the hot and dry mid-August period. In C. v. germari a bimodal pattern could be observed only in the case of females. Although we had a low number of 
Table 1 Number of collected Carabus specimens

\begin{tabular}{llllllll}
\hline Species & Valley 1 & Valley 2 & Valley 3 & Hill 1 & Hill 2 & Hill 3 & Sum \\
\hline Carabus convexus & 0 & 0 & 5 & 9 & 14 & 13 & 41 \\
Carabus coriaceus & 2 & 1 & 9 & 4 & 9 & 4 & 29 \\
Carabus violaceus germari & 93 & 14 & 28 & 5 & 3 & 1 & 144 \\
Carabus hortensis & 0 & 0 & 3 & 0 & 0 & 2 & 5 \\
Carabus nemoralis & 0 & 0 & 0 & 3 & 3 & 11 & 17 \\
Carabus scheidleri & 33 & 25 & 53 & 71 & 38 & 43 & 263 \\
Carabus ullrichii & 43 & 6 & 0 & 11 & 9 & 5 & 74 \\
Sum & 169 & 45 & 95 & 100 & 74 & 41 & 573 \\
\hline
\end{tabular}

collected individuals, it is remarkable that $C$. hortensis completely ceased its activity during the hottest, driest period in August.

\section{Variation in sex ratios}

Sex ratios were significantly female biased in the case of C. scheidleri and C. v. germari and male biased in the case of $C$. convexus. The third most abundant species, $C$. ullrichii did not show any gender bias, neither was such a pattern observable on the summarized data of Carabus spp. (Table 2). Difference between genders in their response to seasonal meteorological variations was detectable only in the case of $C$. scheidleri, where females were affected positively by the maximum temperature values, whereas males were not (Table 3). In a fortnightly break down, considering the pooled Carabus data, significant difference was detectable only in the

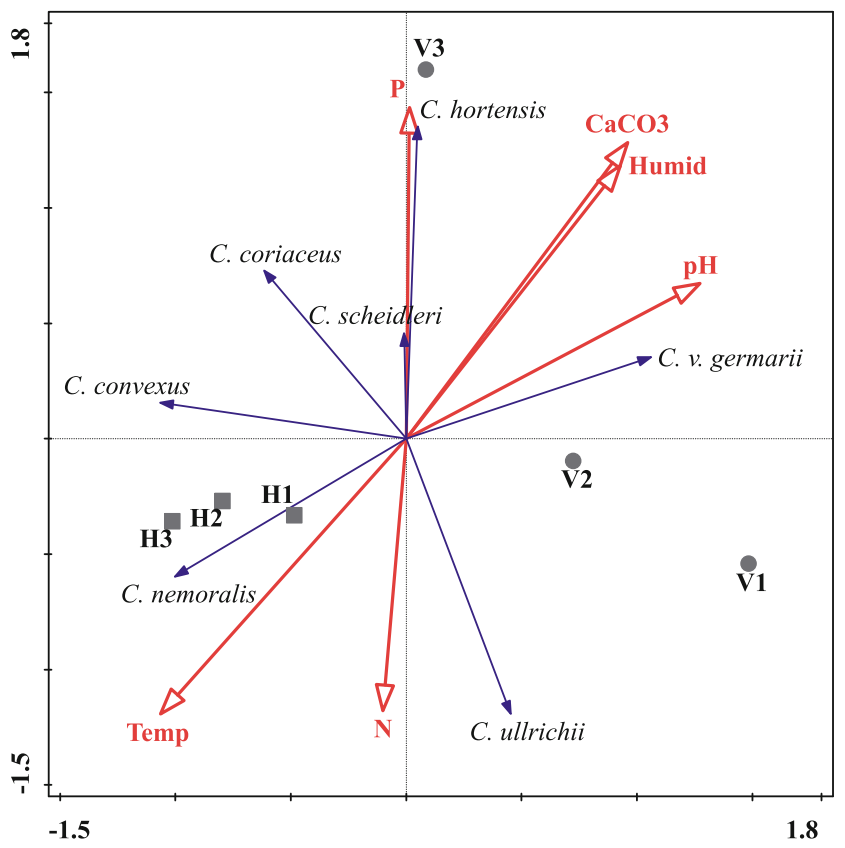

Fig. 3 Redundancy analysis biplot of the Carabus species and the sampling sites constrained by climatic and soil variables (arrows). Axes 1 and 2 hold $59 \%$ and $28 \%$ of the explained variance, respectively second half of June $(N=69 ;$ observed ratio $=0.33 ; \mathrm{z}=-2.77$; $p=0.005$ ), caused by the high number of active $C$. scheidleri females.

\section{Discussion}

Activity density of carabids can change not just between years (Judas et al. 2002) but along much shorter time scales, as well (Huizen 1977; Desender 2000). Patterns found in these studies depended on the resolution of the given study, on the length of sampling periods and on the number of sites sampled. To have a reliable picture about changes in the activity density of Carabus spp., in our research we covered almost the full vegetational period with biweekly temporal resolution. We focused on two forest habitat types (a more humid, and a more dry) represented by three sites each, where pitfall trapping took place in our study. We recorded a moderate variation in the measured microclimatic and soil variables across the sites. This resolution allowed us to establish both spatial and temporal patterns of activity densities and their dependence on environmental variables.

Ground beetle species usually have patchy distribution in a continuous habitat (Rainio and Niemela 2003; Antvogel and Bonn 2008), suggesting that they are strongly influenced by local fine scale micro- habitat variables. This phenomenon can be analysed when individual behaviour of species is observed, for example with radiotelemetry (Bérces and Růžičková 2019). This notion is supported by the present study, since within the six sites of the two locations, covering overall a relatively small area, we could detect different spatial distribution types, specific for some of the species, demonstrating specific microhabitat affinity ranges. On one hand, relative to the extent of the present environmental variability, we could identify generalist species. The overall dominant Carabus scheidleri represented a typical eurytopic dominant species, which occurred at every site with relatively high abundance. Carabus coriaceus and C. ullrichii represented a eurytopic sub-dominant type, being present at (nearly) all sites, but in much lower numbers. On the other hand, some species exhibited a relatively strong association with either of the hill or the valley main habitat type. Carabus nemoralis and 

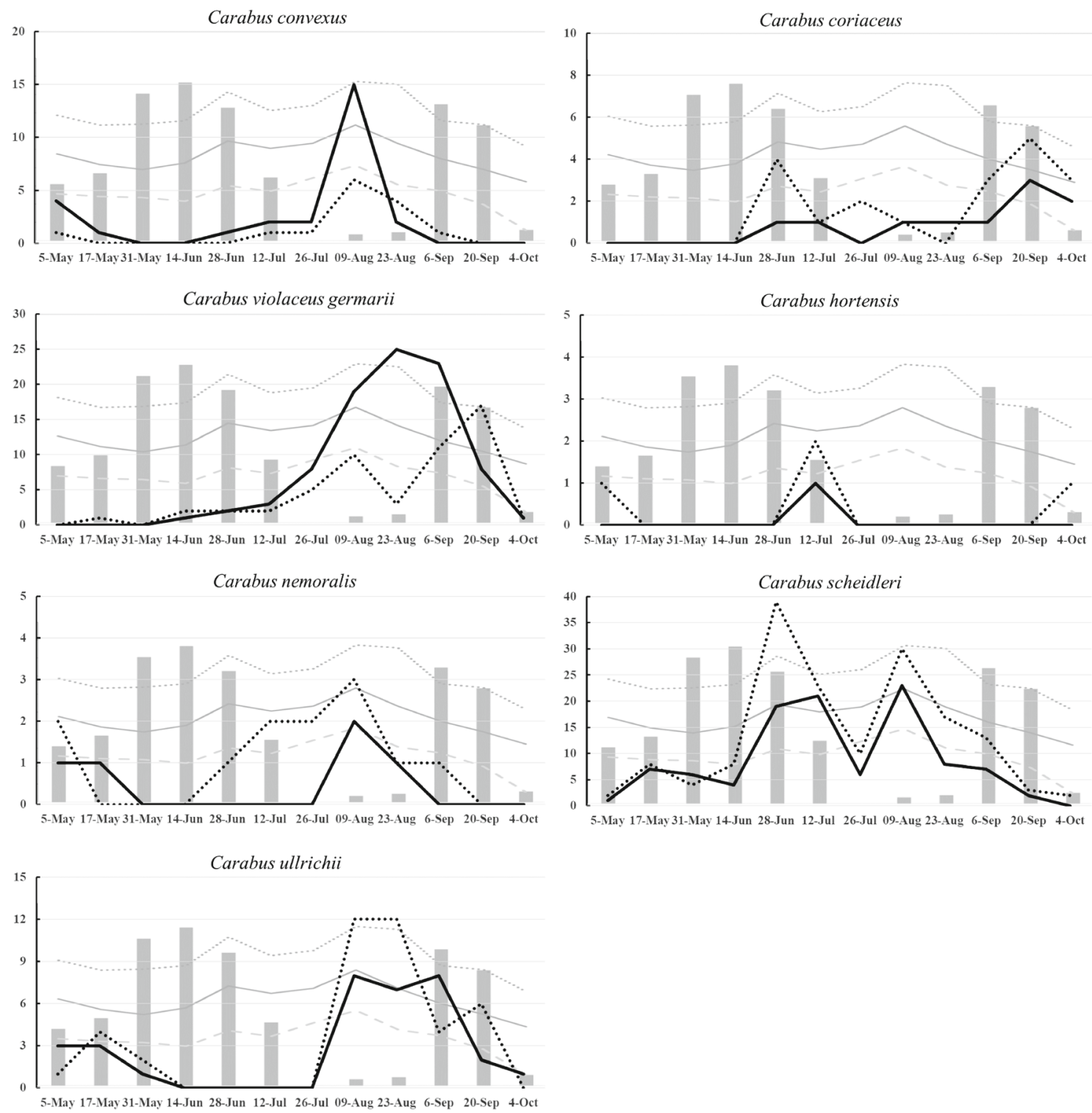

Fig. 4 Number of collected specimens of Carabus spp. with the environmental variables in the background. Axis x: number of collected specimens (not on the same scale), black lines: males, black dotted lines:

females, grey bars: precipitation $(\mathrm{mm})$, grey lines: average temperature, grey dotted lines: minimum temperature, grey dashed line: maximum temperature
Table 2 Number of collected Carabus specimens and the calculated sex ratios

\begin{tabular}{lllllll}
\hline Species & Male & Female & Sum & Sex ratio & Z value & $p$ value \\
\hline Carabus convexus & 27 & 14 & 41 & 0.6585 & 1.8084 & $0.0423 *$ \\
Carabus coriaceus & 10 & 19 & 29 & 0.3448 & -1.8898 & 0.0947 \\
Carabus violaceus germari & 90 & 54 & 144 & 0.625 & 3.000 & $0.0027 * *$ \\
Carabus hortensis & 1 & 4 & 5 & 0.200 & -1.3416 & 0.1797 \\
Carabus nemoralis & 5 & 12 & 17 & 0.2941 & -1.7321 & 0.0896 \\
Carabus scheidleri & 104 & 159 & 263 & 0.3954 & -2.9013 & $0.0007 * * *$ \\
Carabus ullrichii & 33 & 41 & 74 & 0.4459 & -0.4781 & 0.3524 \\
Sum & 234 & 339 & 573 & 0.4712 & -1.3788 & 0.1680 \\
\hline
\end{tabular}

Significant differences are marked with asterisk, $* p<0.05 ; * * p<0.001 ; * * * p<0.0001$ 
Table 3 The effect of fortnightly temperature and humidity data on the activity density of Carabus species tested with Generalized Linear Models (GLM) with Poisson or quasipoisson distribution and log link function. Only species with any significant result are shown

\begin{tabular}{lllllll}
\hline Species/gender & dist. & $p$-values & & & \\
\cline { 3 - 7 } & & Tmin & Tmax & Hmin & Hmax \\
\hline Carabus convexus & qp & 0.00896 & n.s & n.s & n.s \\
Carabus nemoralis & p & 0.0011 & n.s & n.s & n.s \\
Carabus scheidleri & qp & 0.01452 & n.s & n.s & 0.02435 \\
Carabus scheidleri male & qp & 0.000458 & n.s & n.s & 0.023291 \\
Carabus scheidleri female & qp & 0.03522 & 0.02109 & n.s & 0.00158 \\
\hline
\end{tabular}

$T$ temperature, $H$ humidity, dist statistical distribution, $p$ Poisson distribution, $q p$ quasipoisson distribution, n.s. non-significant

C. convexus showing a strong preference, occurred nearly exclusively in the hill habitats. Carabus violaceus germari, while occurring at all sites, exhibited a clear habitat preference, and occurred abundantly only in the valley, showing a much smaller abundance at the hill sites. Our result corresponded to the findings of Néve (1994), indicating that the species responds strongly to humidity levels. Some species, like C. convexus, were associated with the complex abiotic features of their preferred habitat. However, other species showed a strong association with certain abiotic variables, such as $C$. nemoralis showing preference for warm, dry and less limy sites, C. v. germari associated with sites of high-pH soils. This supports the notion that soil is an important additional factor that influences carabid species composition, probably through affecting the development of eggs and larvae (Kotze et al. 2011).

Most Carabus species exhibit biennial (or even longer) iteroparous lifecycle (Matalin 2007). While these species are continually present with their populations in a given habitat, their activity densities can be strongly dependent on external factors, such as the seasonal changes of weather. Although some of the literature proposed humidity as a main factor affecting the dynamics of ground beetles (Šustek 2007), in our samples humidity influenced the activity of only one out of six Carabus species. At the same time, our study rather indicated a responsiveness to temperature, as the activity density of three out of the six investigated species correlated with the minimum temperature, additionally we found the significance of maximum temperature in one species. The above correlational results manifested in specific phenological patterns, which in some species coincided with the hottest periods (C. convexus, $C$. nemoralis, $C$. ullrichii), whereas in others resulted in bimodal patterns that actually had a depression during these peak temperature periods (C. coriaceus, C. hortensis).

It is also remarkable, that there is a correspondence between the temporal and spatial reactions of the species. Scientists long ago have been trying to solve what limiting factors control the habitat affinity of carabid beetles (e.g. Krogerus 1932; Bro Larsen 1936; Krogerus 1948; Lindroth 1949; Krogerus 1960). Thiele (1979) studying Central European carabids in laboratory experiments, concluded that on average the factors of humidity and light were of greater importance than temperature. However, in montane habitats in the temperate zone, he suggested temperature to be the primary factor determining the life cycle of carabids (Thiele 1977). These contrasting results support Park et al. (2017), according to whom responses to environmental variables could differ between communities. Our results indicate a greater importance of temperature in concurrently affecting the temporal dynamics and spatial distribution of Carabus spp. In particular, the hot period active species showed preference for sites with warmer microclimate, whereas aestivating species were more associated to cooler, more humid sites in our study. In the case of $C$. scheidleri a sex biased response was observable.

Overall, the fine scale spatial distribution of Carabus species was affected by microclimatic and soil variables in a complex way. The correlations between weather variables and temporal changes in the Carabus catches suggested that activity density is mostly affected by temperature, often limited by low temperature values. These results indicate that to gain a reliable picture about carabid ecology, studies with sufficient spatial and temporal resolution are necessary.

Acknowledgements Open access funding provided by ELKH Centre for Agricultural Research.

\section{Compliance with ethical standards}

Conflict of interest The authors declare no conflict of interest. Collection permit number: KTVF: 15745-4/2013.

Open Access This article is licensed under a Creative Commons Attribution 4.0 International License, which permits use, sharing, adaptation, distribution and reproduction in any medium or format, as long as you give appropriate credit to the original author(s) and the source, provide a link to the Creative Commons licence, and indicate if changes were made. The images or other third party material in this article are included in the article's Creative Commons licence, unless indicated otherwise in a credit line to the material. If material is not included in the article's Creative Commons licence and your intended use is not permitted by statutory regulation or exceeds the permitted use, you will need to obtain permission directly from the copyright holder. To view a copy of this licence, visit http://creativecommons.org/licenses/by/4.0/.

\section{References}

Althoff G-H, Hockmann P, Klenner M, Nieheus F-J, Weber F (1994) Dependence of running activity and net reproduction in Carabus auronitens on temperature. In: Desender K, Dufrêne M, Loreau M, Luff ML, Maelfait JP (eds) Carabid beetles: ecology and evolution. Springer Netherlands, Dordrecht, pp 95-100. https://doi.org/ 10.1007/978-94-017-0968-2_14 
Andorkó R, Kádár F (2006) Carabid beetle (Coleoptera: Carabidae) communities in a woodland habitat in Hungary. Entomol Fenn 17:221228

Andorkó R, Kádár F (2009) Life-history characteristics of the ground beetle Carabus scheidleri (Coleoptera: Carabidae) in Hungary. Acta Zool Acad Sci Hung 55:381-393

Antvogel H, Bonn A (2008) Environmental parameters and microspatial distribution of insects: a case study of carabids in an alluvial forest. Ecography 24:470-482. https://doi.org/10.1111/j.1600-0587.2001. tb00482.x

Assmann T (2003) Biology and ecology. The genus Carabus in Europe a synthesis. Pensoft Publishers \& European Invertebrate Survey, Sofia-Moscow-Leiden, pp. 287-305

Assmann T, Schroder E, Terlutter H (2000) Morphometric differentiation in a specialised snail predator: Carabus pyrenaeus (Coleoptera: Carabidae). In: natural history and applied ecology of carabid beetles: proceedings of the IXth European Carabidologists' meeting (26-31 July 1998, Camigliatello, Cosenza, Italy), 2000 vol 19. Pensoft Publishers, $\mathrm{p} 171$

Bérces S, Růžičková J (2019) Habitat use of an endangered beetle Carabus hungaricus assessed via radio telemetry. Acta Zool Acad Sci Hung 65:335-348. https://doi.org/10.17109/azh.65.4.335.2019

Bro Larsen E (1936) Biologische Studien über die tunnelgrabenden Käfer auf Skallingen. Videnskabelige Meddelelser fra Dansk Naturhistorisk Forening i Kjøbenhavn 100:1-231

Brouat C, Chevallier H, Meusnier S, Noblecourt T, Rasplus JY (2004) Specialization and habitat: spatial and environmental effects on abundance and genetic diversity of forest generalist and specialist Carabus species. Mol Ecol 13:1815-1826

Butovsky RO (2011) Heavy metals in carabids (Coleoptera, Carabidae). ZooKeys 100. https://doi.org/10.3897/zookeys.100.1529

Cardenas A, Hidalgo JM (2000) Seasonal activity and reproductive biology of the ground beetle Carabus dufouri (Coleoptera: Carabidae). Eur J Entomol 97:329-338

Casale A, Prüser F, Arndt E, Mossakowski D (1998) Phylogenetic relationship in the subgenus Platycarabus Morawitz, 1886 (Coleoptera: Carabidae: Carabini). In: Ball GE, Casale A, Taglianti V (eds) Phylogeny and classification of Caraboidea (Coleoptera: Adephaga). Proceedings of a Symposium (XX Int Congr Entomol), Museo Regionale de Scienze Naturali, Torino, Italy, pp $429-448$

Csonka D (2017) Isopoda közösségek szerveződésének ökomorfológiai háttere. University of Veterinary Medicine Budapest. PhD Dissertation. http://www.huveta.hu/bitstream/handle/10832/1712/ disszertacio_CsonkaDiana.pdf?sequence $=1 \&$ isAllowed $=y$. Accessed 1 Dec 2019

De Laender F et al (2016) Reintroducing environmental change drivers in biodiversity - ecosystem functioning research. Trends Ecol Evol 31: 905-915. https://doi.org/10.1016/j.tree.2016.09.007

Desender K (2000) Flight muscle development and dispersal in the life cycle of carabid beetles: patterns and processes. Entomologie 70: 13-31

Dufrêne M, Legendre P (1997) Species assemblages and indicator species: the need for a flexible asymmetrical approach. Ecol Monogr 67:345-366

Eisenhauer N, Herrmann S, Hines J, Buscot F, Siebert J, Thakur MP (2018) The dark side of animal phenology. Trends Ecol Evol 33: 898-901. https://doi.org/10.1016/j.tree.2018.09.010

Franzen M (1995) Nachweise von Carabus irregularis Fabricius, 1792 aus Rheinland-Pfalz (Coleoptera: Carabidae). Fauna Flora Rheinland-Pfalz 8:5-15

Huizen THP (1977) The significance of flight activity in the life cycle of Amara plebeja Gyll. (Coleoptera, Carabidae). Oecologia 29:27-41

Huk T, Kuhne B (1999) Substrate selection by Carabus clatratus (Coleoptera, Carabidae) and its consequences for offspring development. Oecologia 121:348-354. https://doi.org/10.1007/ s004420050938

Hůrka K (1996) Carabidae of the Czech and Slovak republics. Kabourek, Zlín

Judas M, Dornieden K, Strothmann U (2002) Distribution patterns of carabid beetle species at the landscape-level. J Biogeogr 29:491-508

Kádár F, Fazekas JP, Sárospataki M, Lövei GL (2015) Seasonal dynamics, age structure and reproduction of four Carabus species (Coleoptera: Carabidae) living in forested landscapes in Hungary. Acta Zool Acad Sci Hung 61:57-72. https://doi.org/10.17109/AZH. 61.1.57.2015

Kádár F, Andorkó R, Elek Z (2017) Reproductive characteristics and habitat selection of Carabus ulrichii (Coleoptera, Carabidae) in woodland habitats in Hungary. Acta Zool Acad Sci Hung 63:343354. https://doi.org/10.17109/AZH.63.3.343.2017

Koivula M (2011) Useful model organisms, indicators, or both? Ground beetles (Coleoptera, Carabidae) reflecting environmental conditions. ZooKeys 100:287-314. https://doi.org/10.3897/zookeys.100.1533

Kotze DJ, Brandmayr P, Casale A et al (2011) Forty years of carabid beetle research in Europe - from taxonomy, biology, ecology and population studies to bioindication, habitat assessment and conservation. Zookeys 100:55-148. https://doi.org/10.3897/zookeys.100. 1523

Krogerus R (1932) Über die Ökologie und Verbreitung der Arthropoden der Triebsandgebiete an den Küsten Finnlands. Acta Zool Fenn 12: $1-308$

Krogerus H (1948) Ökologische Untersuchungen über Uferinsekten. Acta Zool Fenn 53:1-157

Krogerus R (1960) Ökologische Studien uber nordische Moorarthropoden. Commentat Biol 21:1-238

Lindroth $\mathrm{CH}$ (1949) Die fennoskandischen Carabidae. Eine tiergeographische Studie. I-III. Kungl Vetensk Vitterh Samh Handl (Ser.B4)

Lövei GL, Sunderland KD (1996) Ecology and behavior of ground beetles (Coleoptera - Carabidae). Annu Rev Entomol 41(1):231-256

Luff M (1975) Some features influencing the efficiency of pitfall traps. Oecologia 19:345-357

Matalin AV (2007) Typology of life cycles of ground beetles (Coleoptera, Carabidae) from western palaearctic. Zool Zh 86:1196-1220

Matern A, Drees C, Kleinwächter M, Assmann T (2007) Habitat modelling for the conservation of the rare ground beetle species Carabus variolosus (Coleoptera, Carabidae) in the riparian zones of headwaters. Biol Conserv 136:618-627

McCune B, Mefford M (2011) PC-ORD. Multivariate analysis of ecological data. Version 6. MjM software design, Gleneden Beach, Oregon, U.S.A

Néve G (1994) Influence of temperature and humidity on the activity of three Carabus species. In: Desender K, Dufrene M, Loreau M, Luff ML, Maelfait JP (eds) Carabid beetles: ecology and evolution. Kluwer Academic Publishers, Dordrecht, pp 189-192

Paarmann W (1973) Bedeutung der Larvenstadien für die Fortpflanzungsrhythmik der Laufkäfer Broscus laevigatus Dej. Und Orthomus atlanticus Fairm. (Col., Carab.) aus Nordafrika. Oecologia 13:81-92. https://doi.org/10.1007/BF00379621

Paarmann W (1986) Seasonality and its control by environmental factors in tropical ground beetles (Col., Carabidae). In: den Boer PJ, Luff ML, Mossakowski D, Weber F (eds) Carabid beetles: their adaptations and dynamics, G. Fischer Verlag, Stuttgart, pp 157-171

Park Y, Kim J, Jang T, Chae H, Takami Y (2017) Local climate mediates spatial and temporal variation in carabid beetle communities in three forests in mount Odaesan. Korea Ecol Entomol 42:184-194. https:// doi.org/10.1111/een.12370

R Core Team (2019) R: A Language and Environment for Statistical Computing. R Foundation for Statistical Computing. https://www. R-project.org 
Rainio J, Niemela J (2003) Ground beetles (Coleoptera : Carabidae) as bioindicators. Biodivers Conserv 12:487-506

Refseth D (1984) The life cycles and growth of Carabus glabratus and C. violaceus in Budalen, Central Norway. Ecol Entomol 9:449-455. https://doi.org/10.1111/j.1365-2311.1984.tb00843.x

Růžičková J, Veselý M (2018) Movement activity and habitat use of Carabus ullrichii (Coleoptera: Carabidae): the forest edge as a mating site? Entomol Sci 21:76-83. https://doi.org/10.1111/ens. 12286

Šerić Jelaska L, Jurasović J, Brown DS, Vaughan IP, Symondson WO (2014) Molecular field analysis of trophic relationships in soildwelling invertebrates to identify mercury, lead and cadmium transmission through forest ecosystems. Mol Ecol 23:3755-3766

Šustek Z (2007) Reactions of carabid communities on wind disaster in high Tatra: a manifestation of species humidity preference. In: 15th International poster day, Transport of water, chemicals and energy in the system soil - crop canopy -atmosphere, Institute of Hydrology, SAS, Bratislava, Vol 15, pp 635-643

Szél G, Retezár I, Bérces S, Fülöp D, Szabó K, Pénzes Z (2007) Magyarország futrinkái. In: Forró L (ed) a Kárpát-medence állatvilágának kialakulása. Magyar Természettudományi Múzeum, Budapest. Magyar Természettudományi Múzeum, Budapest, pp 81106

Szyszko J, Gryuntal S, Schwerk A (2004) Differences in locomotory activity between male and female Carabus hortensis (Coleoptera: Carabidae) in a pine forest and a beech forest in relation to feeding state. Environ Entomol 33:1442-1446. https://doi.org/10.1603/ 0046-225X-33.5.1442

ter Braak CJ, Smilauer P (2012) Canoco reference manual and user's guide: software for ordination, version 5.0. Microcomputer Power, Ithaca, USA

Thiele H-U (1977) Carabid beetles in their environments: a study on habitat selection by adaptations in physiology and behaviour. Zoophysiology and Ecology, Vol 10, Springer-Verlag, Berlin
Thiele H-U (1979) Relationships between annual and daily rhythms, climatic demands and habitat selection in carabid beetles. In: Carabid beetles. Springer, Dordrecht, pp 449-470. https://doi.org/ 10.1007/978-94-009-9628-1_24

Tőzsér D, Magura T, Simon E, Mizser S, Papp D, Tóthmérész B (2019) Pollution intensity-dependent metal accumulation in ground beetles: a meta-analysis. Environ Sci Pollut Res 26:32092-32102. https:// doi.org/10.1007/s11356-019-06294-5

Turin H et al (2003a) Species accounts. In: Turin H, Penev L, Casale A (eds) The genus Carabus in Europe - a synthesis. Pensoft Publishers \& European Invertebrate Survey, Sofia-Moscow-Leiden, pp 151286

Turin H, Penev L, Casale A (eds) (2003b) The genus Carabus in Europe - a synthesis. Pensoft Publishers \& European Invertebrate Survey, Sofia-Moscow-Leiden

Weber F (1966) Zur Verbreitung von Carabus irregularis Fabr. Im Teutoburger Wald und Eggegebirge (Westfalen). Entomologische Blätter für Biologie und Systematik der Käfer (Krefeld) 62:1-5

Weber F, Heimbach U (2001) Behavioural, reproductive and developmental seasonality in Carabus auronitens and Carabus nemoralis (Col., Carabidae). Mitteilungen aus der Biologischen Bundesanstalt für Land-und Forstwirtschaft 382:1-194

Wilson K, Hardy ICW (2002) Statistical analysis of sex ratios: an introduction. In: Hardy ICW (ed) Sex ratios: concepts and research methods. Cambridge University Press, Cambridge, pp 48-92. https://doi.org/10.1017/CBO9780511542053.004

Publisher's note Springer Nature remains neutral with regard to jurisdictional claims in published maps and institutional affiliations. 